\title{
Proposal of three thermodynamic variables to discriminate between storms associated with hail and storms with intense rainfall in Catalonia
}

\author{
C. Farnell and M. C. Llasat \\ Department of Astronomy and Meteorology, Universitat de Barcelona, Barcelona \\ Received: 25-IV-2012 - Accepted: 17-V-2013 - Translated version
}

Correspondence to: mcarme7@gmail.com

\begin{abstract}
Between late spring and early fall, the development of storms is common in Catalonia. Despite the fact that they usually produce heavy showers of short duration, they can also involve severe weather with ice pellets or hail. While the latter usually affect inland regions, and there are numerous publications on these cases; the analysis of events affecting the coast and causing damage to public and private properties is not so well developed. The aim of this study is to provide additional thermodynamic indicators that help differentiate storms with hail from storms without hail, considering cases that have affected various regions of Catalonia, mainly coastal areas. The aim is to give more information to improve prognosis and the ability to detail information in these situations. The procedure developed involved the study of several episodes of heavy rainfall and hail that hit Catalonia during the 2003-2009 period, mainly in the province of Girona, and validated the proposal during the campaign of late summer and fall of 2009, as well as 2012. For each case, several variables related to temperature, humidity and wind were analyzed at different levels of the atmosphere, while the information provided by the radio sounding in Barcelona was also taken into account. From this study, it can be concluded that the temperature difference between $500 \mathrm{hPa}$ and $850 \mathrm{hPa}$, the humidity in the lower layers of the atmosphere and the LI index are good indicators for the detection of storms with associated hail.
\end{abstract}

Key words: thermodynamic variables, intense rainfall, hail, coastal areas, Catalonia

\section{Introduction}

Every year, there are agricultural losses exceeding 650 million Euros in Spain, with Catalonia, specifically the northeast and west regions, being one of the areas where there are most hailstorms (Ceperuelo et al., 2009). The commonest time for them to occur is from April to October, a period in which there is also heavy rainfall and, therefore, there is often considerable difficulty in predicting the meteors associated with the expected storms.

There are several studies dealing with hail in Catalonia. In essence, they can be grouped into three types: specific case studies, those on the Ebro valley and Lleida plain, and those that span all Catalonia. Among the former, there are those by Ceperuelo et al. (2006) on the episode of September 11, 2004, or by Farnell et al. (2009) and Pineda et al. (2009) on the episode of September 17, 2007. With regard to longer periods, there are those by Pascual (2002), who conducted a study of hailstorms on Lleida plain, and by Ceperuelo et al. (2009), which presented a technique for improving the identification of hail in the Ebro valley area using radar observations, an area also referred to in the unpublished study by Merino (2009) on thermodynamic characterization, or Aran et al. (2011), who relates different atmospheric circulation patterns with episodes of hail in Lleida. Finally, among those referring to all Catalonia and covering relatively longer periods, we find the unpublished research developed within the SEVERUS project of the CICYT, by Boshoms (2008) and Bernal (2008), which shows a temporal and spatial analysis of hailstorms in Catalonia in the period between 1996 and 2006, and the reference to the evolution of hailstorms in the context of climate change (Llasat and Corominas, 2010). 


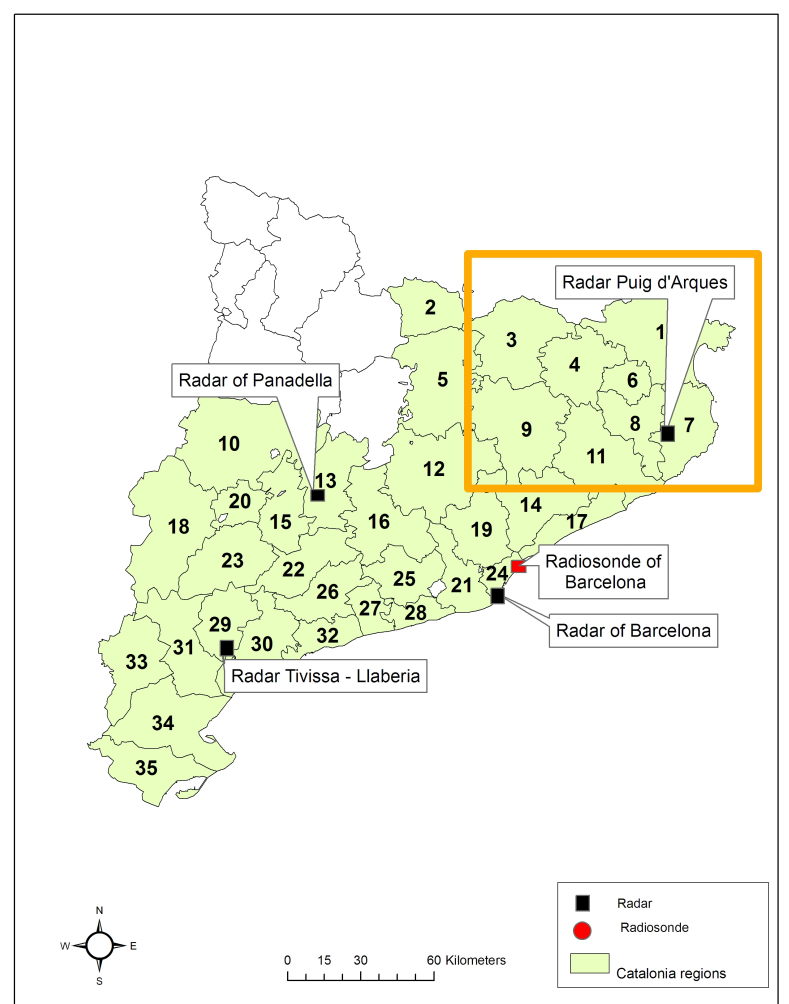

Figure 1. Location of 4 radars of the SMC network (la Panadella, Puig d'Arques, Vallirana i Tivissa-Llaberia) and Barcelona radionsonde station, represented by a red dot. Location of the study area and the north-east sector (box). In green are the regions affected by episodes analyzed and mentioned in Tables 1, 2 and 3. 1 Alt Empordà; 3 Ripollès; 2 Cerdanya; 4 Garrotxa; 6 Pla de l'Estany; 7 Baix Empordà; 8 Gironès; 11 La Selva; 9 Osona; 5 Berguedà; 12 Bages; 14 Vallès Oriental; 17 Maresme; 24 Barcelonès; 19 Vallès Occidental; 21 Baix Llobregat; 28 Garraf; 25 Alt Penedès; 16 Anoia; 13 Segarra; 15 Urgell; 20 Pla d'Urgell; 10 Noguera; 23 Garrigues; 18 Segrià; 22 Conca de Barberà; 26 Alt Camp; 30 Baix Camp; 32 Tarragonès; 29 Priorat; 31 Ribera d'Ebre; 33 Terra Alta; 32 Baix Ebre; 35 Montsià.

Despite the extensive aforementioned literature, there are hardly any works on ice pellets in the coastal areas of Catalonia. That is why the aim of this work is to analyze some episodes of hail and heavy rain that occurred in the northeast of Catalonia with the aim of providing simple criteria that help to distinguish the possibility of storms with or without hail, which can be very useful to complement other procedures that are discussed below. Indeed, unlike the Lleida plain and the Ebro Valley, where most storms produce hail, on the coast they tend to produce heavy rain, and to a lesser extent, rain with ice pellets, or ice pellets or hail without rain.

Deep convection is necessary for the formation of hail. We understand deep convection as a region in which there are strong updrafts $\left(>10 \mathrm{~m} \mathrm{~s}^{-1}\right)$, which spread out to most of the troposphere and have diverse phenomena associated with them, such as: hail, tornadoes, strong winds, heavy rainfall and/or electric discharge (Weisman and Klemp, 1986). The effects produced on the surface are divided according to the severity and intensity of rainfall and the type of precipitation. The National Weather Service (NWS) defines severe storm as a storm that contains one of these phenomena: hailstones of $2 \mathrm{~cm}$ or more in diameter, wind gusts of more than $50 \mathrm{kt}$ or tornadoes. This method is also used by the Spanish Meteorological Agency (AEMET) and the Meteorological Service of Catalonia (SMC).

There are different tools and methodologies to estimate the likelihood of deep convection, or to analyze it. One possibility is the use of weather radar and, in the case of hail, the use of variables such as the density of VIL (the amount of vertically integrated liquid in a column), daytime VIL or Hail Probability Observation (San Ambrosio, 2001; Aran et al., 2007), or the algorithm proposed by Witt et al. (1998). López (2003) defines some indicators to discriminate cells with hail or without hail based on VIL, DVIL, maximum and average reflectivity, cloud ceiling, maximum reflectivity height, volume, mass, speed of the storm, or variation of some variables (cloud top height, volume, etc.) per time unit. Later, Ceperuelo et al. (2009) applied the analysis of the main component technique and reduced the 25 radar parameters to five new variables that explain the physical characterization of the convective cell through 3D observation. These five variables are: i) Intensity; ii) Physical dimensions of the cell; iii) Fusion and cooling level of the convective cell; iv) State of the life cycle of the cell; v) Reflectivity and system organization.

Another possibility, which essentially complements the previous one, is based on the thermodynamic and mesoscale analysis, as in the work of Sánchez et al. (2003). In this case, the necessary factors for the formation of storms and the factors that discriminate between storms and severe storms should be known. The common factors are humidity in lower layers, convective instability and forcing mechanisms (McGingley, 1986). In both cases the presence of intense updrafts is required. Some of the discriminatory factors, which are only formed in severe storms, are the presence of a dry layer at middle levels and wind shear (McGingley, 1986). In addition, there are several factors to consider for the formation of hail: long duration organized structures, height of freezing level and isotherms of $-5^{\circ} \mathrm{C}$ and $-10^{\circ} \mathrm{C}$ (Pascual, 2002), height of the cloud basis (Martín et al., 2007) and cloud top height (Pascual, 2002). The thermodynamic indexes that must be kept in mind are CAPE (Convective Available Potential Energy), the LI (Lifted Index), the TTI (Total Totals Index), the Tc (Convection temperature) and the CCL (Convective Condensation Level). These indexes have also been used in the studies by Rigo (2004), López (2003), Brooks and Craven (2002), Mitzeva et al. (2007) and Kunz (2007).

In the cases discussed below, the previous methodologies have been taken into account, although the focus was put on synoptic, mesoscale and thermodynamic analysis in order to find simple discriminatory policies that helped improve prediction in Catalonia. With this in mind, this article 
Table 1. Episodes studied with the time, hour, place, phenomena, duration and damage produced. The name of the affected region has a number that refers to its location in Figure 1.

\begin{tabular}{|c|c|c|c|c|c|}
\hline & Starting time & Place & $\begin{array}{c}\text { Phenomena and } \\
\text { observations }\end{array}$ & Duration & Damage \\
\hline 20/08/2003 & $18 \mathrm{~h}$ & $\begin{array}{c}\text { Garrotxa (4), } \\
\text { Pla de l'Estany (6) }\end{array}$ & $\begin{array}{l}\text { Hailstone: tennis } \\
\text { balls; intense rain; } \\
\text { strong wind }\end{array}$ & $30 \mathrm{~min}$ & $\begin{array}{l}\text { Broken trees; damaged } \\
\text { cars and houses; foxtail } \\
\text { millet crops destroyed }\end{array}$ \\
\hline $16 / 06 / 2006$ & $14 \mathrm{~h}$ & $\begin{array}{l}\text { Pla d'Urgell (20) } \\
\text { and Urgell (15) }\end{array}$ & $\begin{array}{l}\text { Hailstone of } 4 \mathrm{~cm} ; \\
\text { heavy rain; } \\
\text { small tornado; } \\
\text { lightning } 35,000\end{array}$ & $10-30 \mathrm{~min}$ & $\begin{array}{l}\text { Destroyed crops; } \\
\text { destroyed houses and } \\
\text { sheds; lifted roofs }\end{array}$ \\
\hline $18 / 10 / 2006$ & $12 \mathrm{~h}$ & $\begin{array}{c}\text { Girona regions } \\
(1-4,6-8,11) \text { and Barcelona } \\
(5,9,11,12,14,16,17 \\
19,21,24,25,28)\end{array}$ & 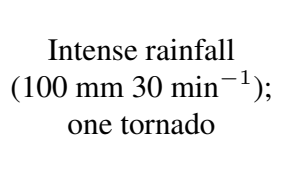 & $\begin{array}{l}\text { During the } \\
\text { afternoon }\end{array}$ & $\begin{array}{l}\text { Flooded basements, } \\
\text { fallen trees, } \\
\text { evacuated schools }\end{array}$ \\
\hline $11 / 09 / 2008$ & $\begin{array}{l}12 \mathrm{~h} \text { in } \\
\text { the Pyrenees; } \\
\text { at } 15 \mathrm{~h} \text { in } \\
\text { Girona } \\
\text { and at } 17 \mathrm{~h} \\
\text { in Lleida }\end{array}$ & $\begin{array}{c}\text { Alt Empordà (1), } \\
\text { Pla de l'Estany (6), } \\
\text { Garrotxa (4) i } \\
\text { Ripollès (3), } \\
\text { Lleida regions } \\
(10,13,15,18,20,23)\end{array}$ & $\begin{array}{l}\text { Hailstone; rain; } \\
\text { strong wind; } \\
\text { thunder and } \\
\text { lightning }\end{array}$ & $15 \mathrm{~min}$ & $\begin{array}{l}\text { Crop losses, especially } \\
\text { apples and peaches; } \\
\text { trees fallen due to the } \\
\text { wind; firemen called out } \\
\text { for floods; road landslides } \\
\text { at Port Ainé (Pallars Sobirà) }\end{array}$ \\
\hline 05/07/2009 & $\begin{array}{c}\text { Early } \\
\text { afternoon }\end{array}$ & $\begin{array}{l}\text { Pla de } \\
\text { l'Estany (6) i } \\
\text { Gironès (8) }\end{array}$ & $\begin{array}{l}\text { Hailstone of } 4 \mathrm{~cm} \text {, } \\
\text { golf balls; } \\
\text { rain and wind }\end{array}$ & $30 \mathrm{~min}$ & $\begin{array}{l}\text { Fallen trees due to the } \\
\text { wind; flooded streets; } \\
\text { crops affected by hailstones }\end{array}$ \\
\hline 09/07/2009 & $12 \mathrm{~h}$ & $\begin{array}{c}\text { Barcelona regions } \\
(5,9,11,12,14,16,17 \\
19,21,24,25,28)\end{array}$ & Intense rainfall & 3 hours & $\begin{array}{c}\text { The most intense were in } \\
\text { the Barcelona regions. They } \\
\text { coincided with the Tour of France }\end{array}$ \\
\hline 04/09/2009 & Mid-afternoon & $\begin{array}{c}\text { Girona regions } \\
(1-4,6-8,11) \text { and Barcelona } \\
(5,9,11,12,14,16,17 \\
19,21,24,25,28)\end{array}$ & Intense rainfall & $\begin{array}{l}\text { During the } \\
\text { afternoon }\end{array}$ & $\begin{array}{l}\text { A river in Rupit burst its } \\
\text { banks. Flooded streets }\end{array}$ \\
\hline
\end{tabular}

is distributed as mentioned below. After this introduction, section two presents the study area. The third point explains the cases that have been studied and the sources of information. Section four explains the methodology used and the fifth point offers the results obtained. Finally, the sixth section gives the conclusions.

\section{Study area and sources of information}

The studies are focused on Catalonia, in the north-east of the Iberian Peninsula (Figure 1). This region is surrounded by the Pyrenees to the north and the coastal and pre-coastal mountain ranges. The Mediterranean Sea lies to the east, and to the west the Lleida plain along with the continuation of the pre-coastal and coastal mountain ranges and the Pyrenees. This highly complex terrain favors the formation of hail, mostly in the summer months, and heavy rain, which causes flooding, especially during the fall months. We analyzed several episodes that have affected this area and, in particular, the province of Girona.

Information from the C-Band Doppler radar network of the SMC and the SMC radio sounding launched daily from the University of Barcelona at 00:00 UTC and 12:00 UTC was used for the analysis of the episodes. Indirectly, the information analyzed in the MONEGRO (REN200309617-C02-02), SEVERUS (CGL2006-13372-CO2-02) and FLASH (Framework Programme European Commission, project no. 036,852) projects, and information from the network of 172 hailstone gauges installed in the Lleida area (Ceperuelo et al., 2009), from the network of 126 rain gauges of the SAIH network of the Catalan Water Agency and from the network of automatic weather stations of the SMC, XEMA (Atencia et al., 2011), was also used to identify the characteristics of the hail surface and precipitation. Data 
Table 2. Episodes analyzed from March to September 2012. The starting time, place and phenomena are shown. The name of the affected region has a number that refers to its location in Figure 1.

\begin{tabular}{cccc}
\hline & Time (UTC) & Place & Phenomena \\
\hline $12 / 09 / 2009$ & $16: 00$ & $\begin{array}{c}\text { Garrotxa (4); Anoia } \\
(16) ; \text { Pla d'Urgell (20) }\end{array}$ & Hail; ice pellets \\
$13 / 09 / 2009$ & $12: 00$ & Baix Camp (30) & $\begin{array}{c}\text { Showers with storm; } \\
\text { hail; ice pellets }\end{array}$ \\
$14 / 09 / 2009$ & $13: 30$ & Barcelonès (24) & Intense showers with \\
storm and ice pellets & Barcelona regions \\
$17 / 09 / 2009$ & From & $(5,9,11,12,14,16,17,19,21,24,25,28)$ & Intense rainfall \\
& $17: 00$ & and Tarragona $(22,26-35)$ & Girona \\
$18 / 09 / 2009$ & $00: 00 \mathrm{~h}$ & regions $(1-4,6-8,11)$ & Intense rainfall \\
\hline
\end{tabular}

from automatic weather stations have also been used for monitoring the events in the validation period.

From the point of view of the weather models, we have worked with: i) the NCEP reanalysis; ii) the MM5 mesoscale maps run by the GAMA group from the UB, according to the parameterizations and explained annually by Barrera et al. (2007).

\section{Selected case studies and information sources}

\subsection{Selected case studies}

The case studies were selected based on four criteria: i) Affected area: sites susceptible to flooding and hailstorms were sought; ii) hail diameter $>2 \mathrm{~cm}$, as in this case significant damage occurs not only to agriculture but also to infrastructures and vehicles, in addition to direct personal injury; iii) High average intensity of rainfall; iv) significant damage.

The cases were selected after a systematic search in the press database developed by the GAMA group, PRESSGAMA (Llasat et al., 2009); the INUNGAMA flood database (Barnolas and Llasat, 2007) according to the homogeneity of the available meteorological information and, finally, the study periods covered by the MONEGRO, SEVERUS and FLASH projects. In all, seven cases included in the 2003-2009 period were selected, focusing on the period of hail tracking campaigns, from May to September, with special emphasis on cases that hit the coast. Some more recent cases, which occurred during the summer of 2009 and during the spring and summer of 2012, have been added to these to validate the findings. Some cases that affected inland areas have been included in order to make a comparison.

Table 1 shows the different episodes studied, the areas most affected, the synthetic description of the phenomena and the damage that they caused. The ANELFA clas-

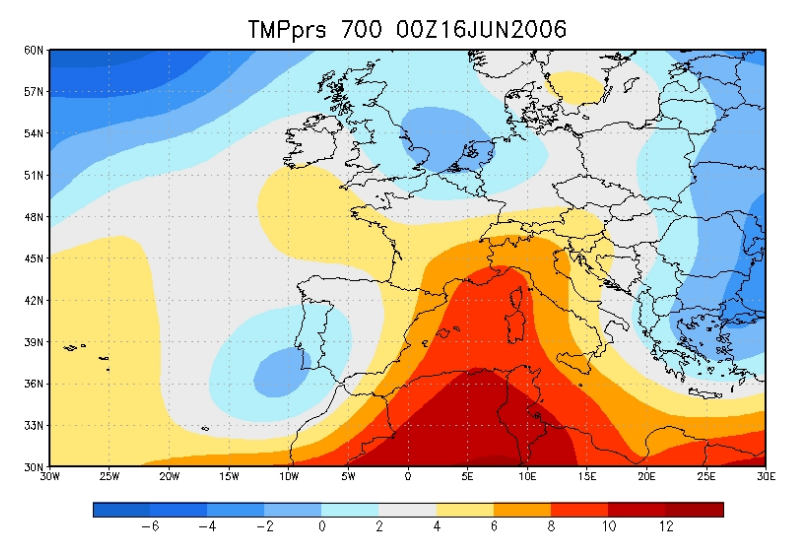

Figure 2. Temperature analysis at $700 \mathrm{hPa}$ on 16 June 2006 at 00:00 UTC.

sification was used to classify the hail according to its size (Dessens et al., 2007).

Five more studies were done later to validate the method (Table 2) and 21 more, three years later (Table 3). The advantage is, that the criteria proposed based on previous analyses on the prediction could be applied, and real-time monitoring of these events was done. The monitoring was done through the various sources explained in section 2 and the results of these analyses can be seen in detail in the results. In this case there was a distinction between ice pellets $(<10 \mathrm{~mm}$ diameter) and hailstones ( $>10 \mathrm{~mm}$ diameter).

\section{Methodology}

The work began by analyzing hail and heavy rain episodes in Table 1. Through these analyses, the selection 
Table 3. pisodes analyzed from March to September 2012. The starting time, place and phenomena are shown. The name of the affected region has a number that refers to its location in Figure 1.

\begin{tabular}{|c|c|c|c|}
\hline & Hour (UTC) & Place & Phenomena \\
\hline $19 / 3 / 2012$ & & Osona (9) & Ice pellets \\
\hline 26/3/2012 & Afternoon & Segrià (18) & Ice pellets \\
\hline $3 / 4 / 2012$ & Afternoon - evening & Pla d’Urgell (20) & Ice pellets \\
\hline $6 / 4 / 2012$ & Afternoon & Interior Tarragona regions $(22,26-35)$ & Ice pellets \\
\hline $12 / 5 / 2012$ & Afternoon & Pyrenees, Pre-Pyrenees, Girona regions $(1-4,6-8,11)$ & Ice pellets \\
\hline $13 / 5 / 2012$ & Afternoon & Maresmes; Osona $(9,17)$ & Ice pellets \\
\hline $19 / 5 / 2012$ & Afternoon & Franja de Ponent $(10,18,31,33)$ & Ice pellets \\
\hline \multirow[t]{3}{*}{$20 / 5 / 2012$} & Morning & Urgell, Pla d'Urgell, Segrià, Garrigues $(15,18,20,23)$ & Ice pellets \\
\hline & Afternoon & Mollet del Vallès (19) & Ice pellets \\
\hline & & Eastern half of Catalonia & Intense rainfall \\
\hline $27 / 5 / 2012$ & Afternoon & Planes d'Hostoles Tordera $(4,17)$ & Ice pellets \\
\hline $12 / 6 / 2012$ & Afternoon & Pyrenees, Pre-Pyrenees, Girona regions $(1-4,6-8,11)$ & Intense rainfall; storms \\
\hline $19 / 6 / 2012$ & Early morning & Palau d'Anglesola (20) & Ice pellets \\
\hline $1 / 7 / 2012$ & Afternoon & Vilafranca del Penedès; Badalona $(24,25)$ & Ice pellets \\
\hline $5 / 7 / 2012$ & Afternoon & $\begin{array}{c}\text { Pla Urgell; Segrià; Urgell; Berguedà; } \\
\text { Bagès; Serra de l'Obach }(5,10,12,15,18,20)\end{array}$ & Hail \\
\hline $27 / 7 / 2012$ & Afternoon & Segrià (18) & Hail, ice pellets \\
\hline 28/7/2012 & Matí & Aldea; Valentins del Montsià (35) & Hail \\
\hline $5 / 8 / 2012$ & Afternoon & Segrià; Noguera $(10,18)$ & Hail, ice pellets \\
\hline $30 / 8 / 2012$ & Morning & General throughout Catalonia & Intense showers \\
\hline \multirow[t]{2}{*}{ 9/9/2012 } & Afternoon & Prat Lluçanès, Castellar del Riu $(5,9)$ & Hail \\
\hline & Afternoon & St Vicenç de Torelló; Rierades Gironella (9) & Ice pellets \\
\hline \multirow[t]{2}{*}{ 10/09/2012 } & Afternoon & Berguedà (5) & Hail, intense rainfall \\
\hline & Afternoon & Alfès $(18)$ & Ice pellets \\
\hline $12 / 9 / 2012$ & Afternoon & Girona regions $(1-4,6-8,11)$ & Intense rainfall \\
\hline
\end{tabular}

of some discriminating factors between rainfall and hail was made. These were examined during two experimental campaigns, which were carried out in September 2009 and during the spring and summer of 2012. The analysis performed includes the steps below.

\subsection{Analysis at a synoptic scale}

Table 4 shows the variables and factors studied for each episode at 00:00 UTC, 06:00 UTC, 12:00 UTC and 18:00 UTC, from the NCEP analysis. First of all, the factors that favor the formation of thunderstorms were taken into consideration (McGingley, 1986; Martín et al., 2007): i) Humidity at medium and low layers, ii) Convective instability, iii) Forcing mechanisms (orographic effects, thermal and humidity boundary, microfronts on a gust, low level jet). Factors discriminating between storms and severe storms were also analyzed (McGingley, 1986; Martín et al., 2007): i) dry layer at middle levels ii) wind shear. It should be noted that the vertical shear with respect to direction favors the deepening and organization of convection. According to López (2003), a very intense shear, especially between 500 and $200 \mathrm{hPa}$, inhibits convection.

The temperature at upper layers was also observed. According to Martín et al. (2007), , clouds generating hail must have their peak at between $-20^{\circ} \mathrm{C}$ and $-40^{\circ} \mathrm{C}$ (5 to $10 \mathrm{~km}$ altitude). Finally, the presence of a close depression is also an important factor to consider, especially due to the convergence that it can create and the organization of the airflow (Rigo and Llasat, 2007).

\subsection{Mesoscale analysis}

The following mesoscale fields, at different levels of the atmosphere (surface, $850 \mathrm{hPa}, 700 \mathrm{hPa}, 300 \mathrm{hPa}$ and $500 \mathrm{hPa}$ ), were analyzed at 00:00, 12:00 UTC and 18:00 UTC, from the outputs of the MM5: i) Temperature, ii) Relative humidity, iii) Wind direction and speed, with special emphasis on areas of convergence. According to Martín et al. (2007), these factors can also behave as forcing mechanisms at mesoscale level. The parameterization and initialization of MM5 used are listed in Barrera et al (2005), but are mainly based on the Kain-Fritsch scheme (Kain and Fritsch, 1993).

\subsection{Thermodynamic and radar analysis}

Different factors and thermodynamic indexes have been analyzed through the Barcelona radio soundings of 00:00 UTC and 12:00 UTC, i) Presence of intense updrafts. The intensity of these drafts is determined by the available convective potential energy, CAPE (Weisman and Klemp, 1986) and the maximum vertical velocity, VMAX (Martín et al., 2007); ii) freezing level height and freezing level of the wet-bulb thermometer (López, 2003; Martín et al., 2007); 
Table 4. Factors analyzed at a synoptic scale for each episode.

\begin{tabular}{lcccccc}
\hline Atmospheric levels & $300 \mathrm{hPa}$ & $500 \mathrm{hPa}$ & $700 \mathrm{hPa}$ & $850 \mathrm{hPa}$ & $925 \mathrm{hPa}$ & Surface \\
\hline Pressure & & & & & & $\mathrm{X}$ \\
Wind maximum & $\mathrm{X}$ & & & & & \\
Wind speed & & $\mathrm{X}$ & $\mathrm{X}$ & $\mathrm{X}$ & $\mathrm{X}$ & \\
Wind direction & $\mathrm{X}$ & $\mathrm{X}$ & $\mathrm{X}$ & $\mathrm{X}$ & $\mathrm{X}$ & \\
Groove & & $\mathrm{X}$ & & & & \\
Vorticity & & $\mathrm{X}$ & & & & \\
Thermal dorsal & & & $\mathrm{X}$ & & & \\
Thermal advection & & & $\mathrm{X}$ & $\mathrm{X}$ & & \\
Temperature & $\mathrm{X}$ & $\mathrm{X}$ & $\mathrm{X}$ & $\mathrm{X}$ & & $\mathrm{X}$ \\
Humidity & & $\mathrm{X}$ & $\mathrm{X}$ & $\mathrm{X}$ & $\mathrm{X}$ & $\mathrm{X}$ \\
\hline
\end{tabular}
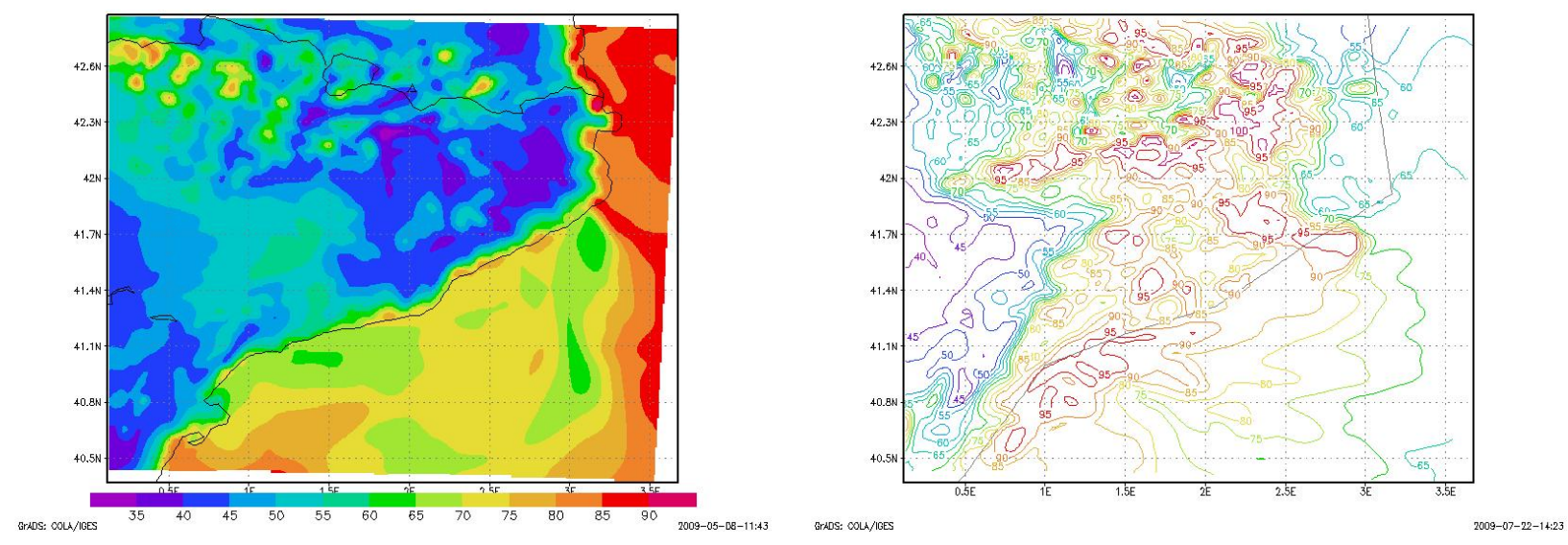

Figure 3. Mesoscale humidity maps at 12:00 UTC. At left (a), hail episode on 11/09/2008. At right (b), rainfall episode of 09/07/2009.

iii) Height of isotherms at $-5^{\circ} \mathrm{C},-10^{\circ} \mathrm{C},-20^{\circ} \mathrm{C}$ (Martín et al., 2007); iv) LI (Galway, 1956); v) Total totals index, TTI (Miller et al., 1972); vi) Lifted condensation level, LCL; vii) Convective condensation level, CCL; viii) Precipitable water mass, PWM.

The radar images were used to follow the evolution of storms and to locate the areas affected by each of them. Subsequently the damage in each of the zones was observed.

\section{Results}

\subsection{Mesoscale and synoptic analysis}

In all cases, whether associated with heavy rain or hail, at $300 \mathrm{hPa}$ the temperature is between $-38^{\circ} \mathrm{C}$ and $-42^{\circ} \mathrm{C}$, without any discriminating difference being found between the two types of episodes. Also, the wind blows from the southwest at this level, with a maximum speed that is between 15 and $20 \mathrm{~m} \mathrm{~s}^{-1}$ in all cases.

Circulation at $500 \mathrm{hPa}$ and $700 \mathrm{hPa}$ is not always well defined. In most episodes, the grooves identified are secondary and their vorticity is small or negligible. However, there are two episodes (16/06/2006 and 18/10/2006), which affected the Lleida and Girona areas, respectively, where a cold closed depression or a deep groove at $500 \mathrm{hPa}$ were found, west of the region. The prevailing wind in the storm front was west or southwest with a speed of between 15 and $20 \mathrm{~m} \mathrm{~s}^{-1}$. In the first of these cases, which affected the province of Lleida, a noticeable south warm air inlet to middle and high levels was observed (Figure 2), placing the affected area in the field of the thermal ridge input. The humidity was below $60 \%$ in all cases except the 09/07/2009 episode of rain that hit the province of Barcelona, where it was $90 \%$.

At $850 \mathrm{hPa}$, the difference in humidity between the hail and rain episodes was marked. In the case of hail, the humidity was below $70 \%$, while in rainfall episodes it exceeded $80 \%$. The common feature was the existence of a small cold air intake, which lowered the temperature between 1 and $2^{\circ} \mathrm{C}$. The wind, also in all cases, was weak and no dominant direction was found.

At $925 \mathrm{hPa}$, the difference in humidity between episodes associated with hail and rain continued to be notable. In the first ones, the humidity was below $70 \%$, whereas in the case of rain the humidity was above $90 \%$. The wind was still very similar to that at $850 \mathrm{hPa}$, being weak and without a dominant direction. 
Table 5. Thermodynamic index for each episode (RDS 12 UTC). The abbreviations are defined in the text.

\begin{tabular}{lccccccc}
\hline & \multicolumn{4}{c}{ Hailstone } & \multicolumn{4}{c}{ Rainfall } \\
& $16 / 06 / 2006$ & $05 / 07 / 2009$ & $11 / 09 / 2008$ & $20 / 08 / 2003$ & $09 / 07 / 2009$ & $04 / 09 / 2009$ & $18 / 10 / 2006$ \\
\hline CCL (m) & 2660 & 2223 & 1685 & 2223 & 463 & 1129 & 1000,9 \\
LCL (m) & 1705 & 909 & 892 & 1292 & 500 & 446 & 704 \\
Freezing level & 3872 & 4050 & 4392 & 3952 & 3812 & 4393 & 3258 \\
LI & -2.3 & -8 & -4.7 & -3.3 & 5.2 & -6.2 & -1.2 \\
TTI & 52.2 & 51 & 46 & 45.6 & 40.3 & 47 & 51.8 \\
CAPE & 283 & 2457 & 1960 & 788 & 0 & 2291 & 233 \\
PWM & 3.46 & 3.26 & 3.61 & 2.81 & 4 & 3.48 & 3.6 \\
Tc & 33.2 & 34.6 & 32 & 37.8 & 23 & 28.2 & 19.6 \\
T850-T500 & 32.6 & 28.3 & 28.1 & 37.2 & 23.0 & 25.9 & 19.0 \\
\hline
\end{tabular}

Table 6. Humidity (\%) at different levels of the atmosphere in the rainfall episodes. The numbers in italics indicate low humidity $(<60 \%)$, while the numbers in bold indicate humidity $>90 \%$. The value of the LI index is also indicated as well as the temperature differences between 850 and $500 \mathrm{hPa}$.

\begin{tabular}{lccccccc}
\hline \multirow{2}{*}{ Episodes } & \multicolumn{3}{c}{ Humidity (\%) at diferent atmospheric levels } & \multicolumn{2}{c}{ Thermodynamic indexes } \\
& $500 \mathrm{hPa}$ & $700 \mathrm{hPa}$ & $850 \mathrm{hPa}$ & $925 \mathrm{hPa}$ & $1000 \mathrm{hPa}$ & $\mathrm{LI}$ & T850-T500 \\
\hline $09 / 07 / 2009$ & 82 & $\mathbf{9 7}$ & $\mathbf{9 5}$ & 89 & 85 & 5.2 & 23 \\
$04 / 09 / 2009$ & 44 & 20 & 81 & $\mathbf{9 5}$ & 65 & -3 & 28.2 \\
$18 / 10 / 2006$ & 69 & $\mathbf{9 8}$ & $\mathbf{1 0 0}$ & 86 & 85 & -1.2 & 19.6 \\
\hline
\end{tabular}

In the mesoscale analysis on surface, differences between episodes of hail and rain were perceived. In the episodes of hail, humidity was below $67 \%$, except in the episode of 16 June 2006 when it was $78 \%$ (Figure 3). In the rainfall episodes, humidity was over $85 \%$ except for the episode of September 4, 2009 when it was $65 \%$.

\subsection{Thermodynamic indexes}

Table 5 shows a summary of the results of the thermodynamic study from Barcelona radio sounding. The analysis of the temperature difference between $500 \mathrm{hPa}$ and $850 \mathrm{hPa}$ showed that in hail episodes it was over $28^{\circ} \mathrm{C}$, in case of rain, the difference was less than $26^{\circ} \mathrm{C}$.

Another indicator that showed differences between the episodes was the convective condensation level (CCL). According to Pascual (2002), if the CCL is too high the updrafts cannot be developed with enough power or may not be developed at all. In all hail cases studied here, the CCL was above $1600 \mathrm{~m}$, while in rainfall episodes it was below $1100 \mathrm{~m}$.

If the Tc is too high, the convection might not even happen (Pascual, 2002). In the analysis done for the different episodes it was found that in hail episodes, the Tc was higher than $32^{\circ} \mathrm{C}$, and in the rainfall episodes it was less than $23^{\circ} \mathrm{C}$, except for the episode of $04 / 09 / 2009$ that had a convection temperature of $28^{\circ} \mathrm{C}$. Therefore, they are temperatures that are found in summer.

In cases of hail, the LI presented low values and in general allowed differentiating cases of hail and rain. In the episodes of hail it had a value of less than -2 . In the cases of rain, it was higher than -1 , except for the episode of 04/09/2009 containing a value of -6 .

The CAPE, TTI and freezing level indexes are good indicators of unstable weather but they are not enough to differentiate cases of hail from those of rain, since the differences between them are poorly marked.

\subsection{Selection of the more discriminant variables}

In the previous section, for each of the cases mentioned, nine variables between $300 \mathrm{hPa}$ and $1000 \mathrm{hPa}$ and $10 \mathrm{in}-$ dexes calculated from radio soundings were analyzed. Tables 6 and 7 seek to synthesize the most representative variables and the ones that indicated differences between the episodes of hail and those of rain.

In the analysis of the maps, a single significant difference was observed, humidity at low levels. To work with this variable more accurately, the humidity values at different levels were taken from the radio soundings at 00:00 and 12:00 UTC. It was observed that in the rainfall episodes the humidity was above $95 \%$ between $850 \mathrm{hPa}$ and $925 \mathrm{hPa}$ (Table 6). However, in hail episodes the humidity was below $85 \%$ and $100 \%$ humidity was never reached (Table 7 ).

In the thermodynamic analysis, the temperature difference between $500 \mathrm{hPa}$ and $850 \mathrm{hPa}$ and the LI index are good indicators. This difference was higher than $28^{\circ} \mathrm{C}$ in hail episodes and below this threshold in rainfall episodes. The LI index was less than -2 in hail episodes, and higher than -1 in rain episodes. In some way, these results are consistent with those obtained by Gibergans-Bàguena and Llasat (2007) after analyzing 2393 (00:00 UTC) and 2265 (12:00 UTC) ra- 
Table 7. Humidity $(\%)$ at different levels of the atmosphere in hail episodes. The numbers in italics indicate low humidity $(<60 \%)$, while the numbers in bold indicate humidity $>90 \%$. The value of the LI index is also indicated as well as the temperature differences between 850 and $500 \mathrm{hPa}$.

\begin{tabular}{lccccccc}
\hline \multirow{2}{*}{ Episodes } & \multicolumn{3}{c}{ Humidity (\%) at diferent atmospheric levels } & \multicolumn{2}{c}{ Thermodynamic indexes } \\
& $500 \mathrm{hPa}$ & $700 \mathrm{hPa}$ & $850 \mathrm{hPa}$ & $925 \mathrm{hPa}$ & $1000 \mathrm{hPa}$ & $\mathrm{LI}$ & T850-T500 \\
\hline $16 / 06 / 2006$ & 38 & 83 & 61 & 56 & 78 & -2.3 & 33.2 \\
$05 / 07 / 2009$ & 44 & 43 & 83 & 74 & 55 & -4.8 & 34.6 \\
$11 / 09 / 2008$ & 28 & 71 & 63 & 76 & 67 & -5.6 & 31.5 \\
$20 / 08 / 2003$ & 22 & 50 & 28 & 47 & 52 & -3.3 & 37.8 \\
\hline
\end{tabular}

Table 8. Factors and indexes analyzed to corroborate or reject the hypothesis. The numbers in italics indicate low humidity $(<60 \%)$, while the numbers in bold indicate humidity $>90 \%$. The value of the LI index is also indicated as well as the temperature differences between 850 and $500 \mathrm{hPa}$.

\begin{tabular}{lcccccccc}
\hline \multirow{2}{*}{ Episodes } & \multirow{2}{*}{ Hour (UTC) } & \multicolumn{4}{c}{ Humidity (\%) at diferent atmospheric levels } & \multicolumn{3}{c}{ Thermodynamic indexes } \\
& & $500 \mathrm{hPa}$ & $700 \mathrm{hPa}$ & $850 \mathrm{hPa}$ & $925 \mathrm{hPa}$ & $1000 \mathrm{hPa}$ & LI & T850-T500 \\
\hline $12 / 09 / 2009$ & 12 & 72 & 65 & 48 & 53 & 50 & -1.4 & 30 \\
$13 / 09 / 2009$ & 00 & 67 & 90 & 47 & 65 & 56 & -1.1 & 28.5 \\
& 12 & 58 & 85 & 75 & $\mathbf{1 0 0}$ & 72 & -1.1 & 28.5 \\
$14 / 09 / 2009$ & 00 & 80 & $\mathbf{9 2}$ & 61 & 80 & 72 & -1.7 & 26,6 \\
& 12 & 67 & 55 & 88 & 73 & $\mathbf{9 4}$ & 2,9 & 24.1 \\
$17 / 09 / 2009$ & 12 & 65 & $\mathbf{9 3}$ & 75 & 65 & 60 & 0 & 24.5 \\
$18 / 09 / 2009$ & 00 & 64 & 83 & 76 & 75 & $\mathbf{9 1}$ & -1.43 & 26.4 \\
\hline
\end{tabular}

dio soundings in Palma de Mallorca for the 1975-1989 period, and searching among 22 thermodynamic parameters, the most discriminated ones on the rainfall in Catalonia. Of the seven indexes obtained, LI and relative temperature at $850 \mathrm{hPa}$ were two of them.

The rain episode of 4th September 2009 was studied more thoroughly, as during the analysis it was observed that the values obtained for different indexes the CCL and Tc, were close to the values of the hail cases, and the LI index obtained an equal value. The question is, why was there no hail? While this study cannot give a conclusive answer, it is possible to observe that below $850 \mathrm{hPa}$, the humidity was above $90 \%$.

\subsection{Hypothesis validation}

In September 2009, there was a monitoring campaign to corroborate or refute the hypotheses developed in the previous analysis. We analyzed five episodes of heavy rain and/or ice pellets or hailstones (Table 2). The factors analyzed in these episodes were humidity ranging from the $500 \mathrm{hPa}$ and $1000 \mathrm{hPa}$ levels, the thermodynamic index LI, and the difference between the temperature of $500 \mathrm{hPa}$ and $850 \mathrm{hPa}$. Table 8 shows how the humidity at $850 \mathrm{hPa}$ was below $50 \%$ in only two cases where there were hailstones, and in the cases where rain prevailed, it was over $75 \%$ at this level. The detailed study of all levels between $850 \mathrm{hPa}$ and the surface showed that it was over $95 \%$ in the cases dominated by rain.

Regarding the thermodynamic index, it was observed that the lifted index was less than -1 in cases dominated by hail, in which the difference of temperature between $500 \mathrm{hPa}$ and $850 \mathrm{hPa}$ was below $28^{\circ} \mathrm{C}$ (Table 8 ).

During 2012, there was a second experimental campaign held between March and September (Table 3), taking episodes of heavy rain, ice pellets and hailstones. Of the 21 case studies that were selected, hailstorms were recorded in only six of them, and heavy rains and/or hail in the rest of them. Of those six episodes and attending to radio soundings in Barcelona and Zaragoza, they all showed values of LI $<-3$, humidity below $80 \%$ ( 5 of them below $70 \%$ ) and the temperature difference in the middle levels was above $28^{\circ} \mathrm{C}$. However, in none of the other cases in which there was either rain or rain accompanied by ice pellets, were these three conditions met.

\section{Conclusions}

From the meteorological analysis of 33 cases of storms with rain and thunderstorms with hail that happened between 2003 and 2012, through 9 variables and 10 thermodynamic indexes, we conclude that there are three thermodynamic indexes that can help differentiate storms with hail from storms without hail. Thus, values of $\mathrm{LI}<-2$, differences in temperature between $850 \mathrm{hPa}$ and $500 \mathrm{hPa}$ over $28^{\circ} \mathrm{C}$ and humidity between the surface and $850 \mathrm{hPa}$ below $70 \%$, are the main indicators. In contrast, in rainfall episodes the LI is usually higher than -1 , humidity at low levels exceeds $85 \%$ and the average temperature gradient at middle levels is considerably lower than in the case of ice pellets. 
This result is consistent with the production of severe storms as opposed to storms with intense rain in the study area. In the case of hailstorms, it shows the significant instability in middle levels, which in the case of rainfall is concentrated mainly at low levels, as well as the requirement for higher humidity in the latter cases. In the study of GibergansBàguena and Llasat (2007) about discriminated thermodynamic factors of heavy rainfall in Catalonia, from the radio soundings made in Mallorca, the importance of high values of precipitable water mass between 700 and $500 \mathrm{hPa}$ and high temperatures at low levels were already detected. Moreover, the synoptic situation shows similar characteristics associated with spring, summer and early fall storms in both types of cases, with the presence of a trough to the west, or a close depression, the intake of warm air at low levels. The marked temperature gradient observed in hail cases suggests a relatively cold air intake on middle levels.

Acknowledgements. This work was initiated as part of the Ministry of Education and Science, SEVERUS (CGL2006-13372-CO202) project. Our thanks to Montserrat Aran, Tomeu Rigo and the Prediction and Monitoring Team of the Meteorological Service of Catalonia for the data provided, as well as to A. Merino, M. Bernal and M. Boshoms, for giving us access to their masters' theses.

\section{References}

Aran, M., Sairouni, A., Bech, J., Toda, J., Rigo, T., Cunillera, J., and Moré, J., 2007: Pilot project for intensive surveillance of hail events in Terres de Ponent (Lleida), Atmos Res, 83, 315335.

Aran, M., Peña, J. C., and Torà, M., 2011: Atmospheric circulation patterns associated with hail events in Lleida (Catalonia), Atmos Res, 100, 428-438.

Atencia, A., Mediero, L., Llasat, M. C., and Garrote, L., 2011: Effect of radar rainfall time resolution on the predictive capability of a distributed hydrologic model, Hydrol Earth Syst Sci, $\mathbf{1 5}$ 3809-3827, doi:10.5194/hess-15-3809-2011.

Barnolas, M. and Llasat, M. C., 2007: A flood geodatabase and its climatological applications: the case of Catalonia for the last century, Nat Hazards Earth Syst Sci, 7, 271-281.

Barrera, A., Altava-Ortiz, V., Llasat, M. C., and Barnolas, M., 2007: Heavy rain prediction using deterministic and probabilistic models. the flash flood cases of 11-13th October 2005 in Catalonia (NE of Spain), Advances in Geosciences, 12, 121-126, doi:10.5194/adgeo-12-121-2007.

Bernal, M., 2008: Aplicación de un SIG al análisis espacial de las tormentas de granizo en el NE de la Península Ibérica, Universitat de Barcelona, Barcelona, treball del Màster Oficial en Meteorologia.

Boshoms, M., 2008: Tempestes de calamarsa a Catalunya. Cap a la creació duna base de dades depisodis de calamarsa. Anàlisi temporal per al període (1996-2006), Universitat de Barcelona, Barcelona, treball del Màster Oficial en Meteorologia.

Brooks, H. E. and Craven, J. P., 2002: A database of proximity soundings for significant severe thunderstorms, 1957-1993, American Meteorological Society, Preprints, 21st Conference on Severe Local Storms, San Antonio, TX, 639-642.
Ceperuelo, M., Llasat, M. C., López, L., García, E., and Sánchez, J. L., 2006: Study of 11 September 2004 hailstorm event using radar identification of $2 D$ systems and $3 D$ cells, Advances in Geosciences, 1, 215-222.

Ceperuelo, M., Rigo, T., Llasat, M. C., and Sánchez, J. L., 2009: Improving hail identification in the Ebro valley region using radar observations: probability equations and warning thresholds, Atmos Res, 93, 474-482.

Dessens, J., Berthet, C., and Sánchez, J. L., 2007: A point hailfall classification based on hailpad measurements: The ANELFA scale, Atmos Res, 83, 132-139.

Farnell, C., Aran, M., Andrés, A., Busto, M., Pineda, N., and Torà, M., 2009: Study of the September 17th 2007 severe hailstorm in Pla d'Urgell. Part I: fieldwork and analysis of the hailpads, Tethys, 6, 69-81, doi: 10.3369/tethys.2009.6.05.

Galway, J. G., 1956: The lifted index as a predictor of latent instability, Bull Amer Meteorol Soc, 37, 528-529.

Gibergans-Bàguena, J. and Llasat, M. C., 2007: Improvement of the analog forecasting method by using local thermodynamic data. Application to autumn precipitation in Catalonia, Atmos Res, 86, 173-193.

Kain, J. S. and Fritsch, J. M., 1993: Convective parameterization for mesoscale models: The Kain-Fritsch scheme, in: The representation of cumulus convection in numerical models, Emanuel, K. A. and Raymond, D. J., Meteorological Monograph of the American Meteororological Society, 46, 165-170.

Kunz, M., 2007: The skill of convective parameters and indices to predict isolated and severe thunderstorms, Nat Hazards Earth Syst Sci, 7, 327-342.

Llasat, M. C. and Corominas, J., 2010: Riscos associats al clima. Segon informe sobre el canvi climàtic a Catalunya, J.E. Llebot (coord.), Institut dEstudis Catalans i Generalitat de Catalunya, Departament de la Vicepresidència, Consell Assessor per al Desenvolupament Sostenible de Catalunya, pp. 243-307, ISBN (IEC): 978-84-9965-027-2, ISBN (Gencat): 978-84-393-8615-5, Dipòsit Legal: B. 44160-2010, 2010.

Llasat, M. C., Llasat-Botija, M., and López, L., 2009: A press database on natural risks and its application in the study of floods in northeastern Spain, Nat Hazards Earth Syst Sci, 9, 2049-2061, doi:10.5194/nhess-9-2049-2009.

López, L., 2003: Convección atmosférica severa: pronóstico e identificación de tormentas de granizo, Universidad de León, tesis doctoral, 207 pp.

Martín, F., Elizaga, F., Carretero, O., and San Ambrosio, I., 2007: Diagnóstico y predicción de la convección profunda, STAP Nota técnica Núm. 35.

McGingley, J., 1986: Nowcasting Mesoscale Phenoma, ed. P.S. Ray, American Meteorological Society, Boston, Massachussets, 657-688.

Merino, A., 2009: Caracterización termodinámica de la atmósfera en situaciones de granizo en el valle medio del Ebro y comparación con otras regiones de formación de tormentas, Universitat de Barcelona, Barcelona, treball del Master Oficial en Meteorologia.

Miller, R. C., Bidner, A., and Maddox, R. A., 1972: Notes on analysis and severe storm forecasting procedures of the air force global weather control, AFGWC Tech. Rep 200, Air Weather Service, US Air Force, 102 pp.

Mitzeva, R., Dimitrova, T., and Savtchenco, A., 2007: Enviromental conditions responsible for the type of precpitation in summer convective over Bulgaria, Faculty of Physics, University of Sofia 
and Agency Hail Suppression, Sofia, Bulgaria.

Pascual, R., 2002: Estudio de las granizadas en el llano de Lleida, Nota técnica núm. 3. Centro Meteorológico Territorial de Catalunya, http://www.aemet.es/es/divulgacion/varios/ detalles/biblioteca_tempoweb.

Pineda, N., Aran, M., Andres, A., Busto, M., Farnell, C., and Torà, M., 2009: Study of the September 17th 2007 severe hailstorm in Pla d'Urgell. Part II: meteorological analysis, Tethys, 6, 83-103, doi: 10.3369/tethys.2009.6.06.

Rigo, T., 2004: Estudio de sistemas convectivos mesoescalares en la zona mediterránea occidental mediante el uso de radar meteorológico, tesis doctoral, $215 \mathrm{pp}$.

Rigo, T. and Llasat, M. C., 2007: Analysis of mesoscale convective systems in Catalonia (NE of Spain) using radar for the period 1996-2000, Atmos Res, 83, 458-472.

San Ambrosio, I., 2001: Primera valoración de algoritmos para la estimación de la probabilidad de ocurrencia de granizo, V Simposio Nacional de Predicción. Memorial "Alfonso Ascaso", Madrid 20-23 Noviembre 2001, 6 pp.

Sánchez, J. L., Fernández, M. V., Fernández, J. T., Tudurí, E., and Ramis, C., 2003: Analysis of mesoscale convective systems with hail precipitation, Atmos Res, 67-68, 573-588.

Weisman, M. L. and Klemp, J. B., 1986: Characteristics of Isolated Convective Storms. Mesoscale Meteorology and Forecasting, Ed. P.S. Ray, American Meteorological Society, Boston, Massachussets, 331-358.

Witt, A., Eilts, M. D., Stumpf, G. J., Johnson, J. T., Mitchell, E. D., and Thomas, K. W., 1998: An enhanced hail detection algorithm for the WSR-88D, Weather Forecast, 13, 286-303. 